\title{
Vitamin D Dependent Rickets Type 1A Caused by CYP27B1 Mutation
}

\section{Na Ry Bak, M.D. \\ Eun Song Song, M.D. Eun Mi Yang, M.D. Chan Jong Kim, M.D.}

Department of Pediatrics, Chonnam National University Medical School \& Children's Hospital, Gwangju, Korea

\author{
Corresponding author: \\ Eun MiYang, M.D. and Chan Jong Kim, M.D. \\ Department of Pediatrics, Chonnam \\ National University Medical School \& \\ Children's Hospital, 42 Jebong-ro, Dong- \\ Gu, Gwangju 61469, Korea \\ Tel: +82.62-220-6647 \\ Fax: $+82.62-222-6103$ \\ E-mail:emyang@chonnam.ac.kr \\ cjkim@jnu.ac.kr
}

Received: 3 April 2019

Revised: 7 June 2019

Accepted: 22 June 2019
Vitamin $\mathrm{D}$ dependent rickets type $1 \mathrm{~A}$ (VDDR1A) is an autosomal recessive disorder caused by mutations in CYP27B1. Clinical findings are growth retardation, hypotonia, muscle weakness, hypocalcemic seizures, and radiological features of rickets. We aimed to present the VDDR1A case with a genetic study of CYP27B1. The 14month-old boy was admitted to the hospital due to a seizure. Serum calcium, phosphorus, alkaline phosphatase, parathyroid hormone (PTH), 25(OH) vitamin $\mathrm{D}$, and 1,25(OH)2 vitamin D values were $5.1 \mathrm{mg} / \mathrm{dL}, 3.7 \mathrm{mg} / \mathrm{dL}, 705 \mathrm{IU} / \mathrm{L}, 429 \mathrm{pg} / \mathrm{mL}$, $24.9 \mathrm{ng} / \mathrm{mL}$, and $8.8 \mathrm{pg} / \mathrm{mL}$, respectively. Radiological study showed cupping and fraying of the distal ulna and radius. The molecular genetic study revealed that the patient had a compound heterozygous mutation, Phe443Profs*24 and c.589+ $1 \mathrm{G}>\mathrm{A}$, in CYP27B1. Genetic analysis of the family members presented that the mother was heterozygous for the mutation c.589+1G>A, and that the father was heterozygous for Phe443Profs ${ }^{*} 24$. The patient was treated with calcium lactate and calcitriol. Until now, six Korean patients with VDDR1A have been studied. Including this case, Korean patients with VDDR1A were found to have only three different mutations in 14 alleles, indicating that the mutation in the CYP27B1 gene is homogeneous in the Korean population.

Key words: Rickets, CYP27B1 gene, Vitamin D dependent rickets type 1A

\section{Introduction}

There are two types of vitamin D: ergocalciferol (D2) and cholecalciferol (D3). Two types of vitamin $\mathrm{D}$ are biologically inactive prohormones, and it is necessary to undergo two enzymatic conversions in the liver and kidney ${ }^{1,2}$. $C Y P 2 R 1$ catalyzes the initial hydroxylation step in the liver converting vita$\min \mathrm{D}$ to $25(\mathrm{OH})$ vitamin $\mathrm{D}(25 \mathrm{OHD})$. Albeit $25 \mathrm{OHD}$ is the most plentiful type of vitamin $\mathrm{D}$ in circulation, it has minimal ability bind to the vitamin $\mathrm{D}$ receptor (VDR) $)^{3)}$. The 25OHD 1a-hydroxylase gene (CYP27B1) encodes the 1a-hydroxylase enzyme, which catalyzes $25 \mathrm{OHD}$ to $1,25(\mathrm{OH}) 2$ vitamin $\mathrm{D}$ $[1,25(\mathrm{OH}) 2 \mathrm{D}]$. The $1,25(\mathrm{OH}) 2 \mathrm{D}$ is the active type of vitamin $\mathrm{D}$ that acts via the VDR to increase the expression of genes. It is stimulated by parathyroid hormone (PTH), hypocalcemia, and hypophosphatemia ${ }^{4,5)}$.

Vitamin D dependent rickets type 1A (VDDR1A), also known as vitamin D la-hydroxylase deficiency or pseudovitamin D deficiency rickets, is an autosomal recessively inherited disorder resulting from defects in the CYP27B1. The associated clinical findings are growth retardation, hypotonia, muscle 
weakness, hypocalcemic seizures, and radiological features of rickets. Biochemical findings show hypocalcemia, elevated PTH, and decreased values of $1,25(\mathrm{OH}) 2 \mathrm{D}$ in spite of normal or elevated concentrations of 25OHD. Generally, a good response to medication with alfacalcidol or calcitriol is estimated for patients with VDDR1A ${ }^{6,7)}$. Calcitriol and calcium treatment was modified based on the laboratory and clinical features. Treatment results in the normalization of laboratory parameters and radiographic abnormalities within 3 months.

So far, six Korean patients with VDDR1A have been investigated at a genetic study ${ }^{8-10)}$. We now report the results of clinical and molecular genetic studies of CYP27B1 mutations in one additional patient and review the findings in all reported Korean patients with $C Y P 27 B 1$ defects.

\section{Case report}

A 14-month-old boy was admitted in our hospital due to a generalized tonic seizure lasting for two minutes. He was born to non-consanguineous Korean parents as their first baby at 40 weeks of gestation. The boy was healthy at birth and weighed 4,220 g. The parents were healthy and they do not have any hereditary disorders. At the age of 9 months, he had the ability to crawl, and at 13 months, he was able to walk alone. At a physical examination, he was $77.0 \mathrm{~cm}$ tall (25-50 percentile) and weighed $9.5 \mathrm{~kg}$ (10-25 percentile).

Laboratory profile showed as follows; serum total calcium of $4.8 \mathrm{mg} / \mathrm{dL}$ (normal range, $8.4-10.2 \mathrm{mg} / \mathrm{dL}$ ); ionized calcium of $1.4 \mathrm{mEq} / \mathrm{L}$ (normal range, $2.2-2.6 \mathrm{mEq} / \mathrm{L}$ ); phosphorus of $3.7 \mathrm{mg} / \mathrm{dL}$ (normal range, $3.8-6.5 \mathrm{mg} / \mathrm{dL}$ ), alkaline phosphatase of $705 \mathrm{U} / \mathrm{L}$ (normal range, 145-420 $\mathrm{U} / \mathrm{L}$ ); and PTH of $429 \mathrm{pg} / \mathrm{mL}$ (normal range, $10-65 \mathrm{pg} / \mathrm{mL}$ ). $25 \mathrm{OHD}$ level was $24.9 \mathrm{ng} / \mathrm{mL}$ (normal range, 30-90 pg/ $\mathrm{mL}$ ) and $1,25(\mathrm{OH}) 2 \mathrm{D}$ was $8.8 \mathrm{pg} / \mathrm{mL}$ (normal range, 20$55 \mathrm{pg} / \mathrm{mL}$ ). Radiological study showed cupping and fraying of the distal ulna and radius (Fig. 1). The above laboratory and radiological signs were compatible with a diagnosis of rickets. A decreased 1,25(OH)2D level with relatively normal 25OHD and very high PTH concentrations indicated a diagnosis of a genetic type of rickets, precisely $1 \alpha-$ hydroxylase deficiency.

A mutation analysis of the CYP27B1 gene was performed.
Genomic DNA was extracted from leukocytes. All coding exons and intron in flanking regions of $C Y P 27 B 1$ were amplified by polymerase chain reaction and directly sequenced. The primers used for DNA sequencing of patients were as previously described ${ }^{8)}$. Molecular genetic study revealed that the patient had a compound heterozygous mutation for the 7-bp duplication 1319-1325dupCCCACCC (Phe443Profs ${ }^{\star} 24$ ) and c.589+1G $>A$ in the CYP27B1 gene (Fig. 2). The family members revealed that the mother was heterozygous for the mutation $\mathrm{c} .589+1 \mathrm{G}>\mathrm{A}$, and the father was heterozygous for Phe443Profs ${ }^{\star} 24$. G to A substitution in the first nucleotide of intron 3 (c. $589+1 \mathrm{G}>\mathrm{A}$ ) was reported previously in Japanese and Korean patients ${ }^{8-11)}$. The Phe443 Profs $^{\star} 24$ mutation was reported in multiple ethnic groups including Korean population ${ }^{8)}$.

The boy was treated with calcitriol and calcium lactate. Compliance with the supplementation was good, resulting in quick improvement of the abnormal clinical, laboratory, and radiographic findings. The patient showed normocalcemia without recurrent hypocalcemic seizures. Radiologic study showed marked improvement after 5 months of treatment (Fig. 1).

\section{Discussion}

There are four types of genetic errors in vitamin D me-

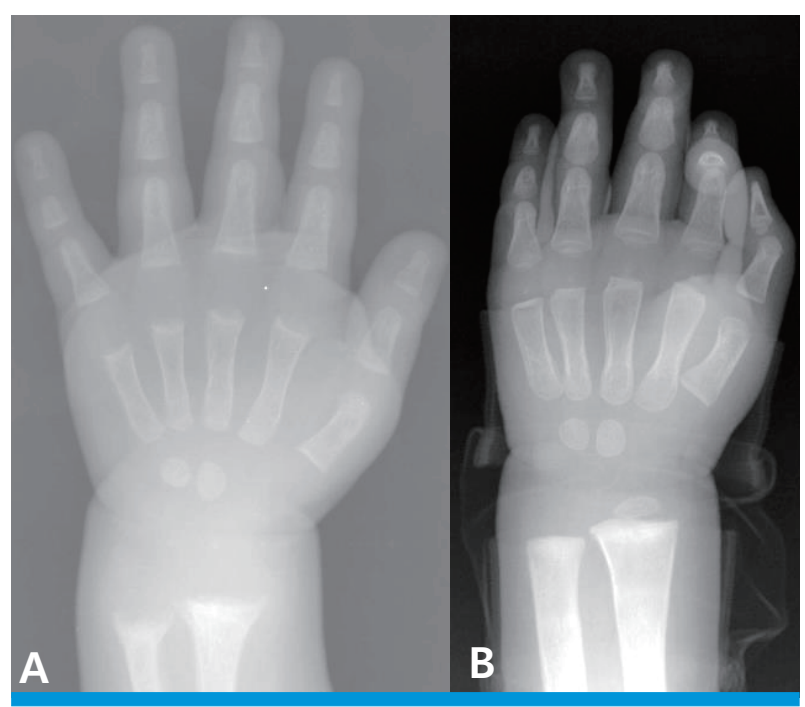

Fig. 1. Radiographic features of the patient. (A) X-ray finding showed cupping and fraying of the metaphyseal regions of radius and ulnar at presentation. (B) After 5 months of treatment, bone lesions were markedly improved. 
tabolism, and it can cause rickets. The first type is the VDDR1A, which is caused by defects in the CYP27B1 gene. A mutation in the $C Y P 2 R 1$ gene that results in 25-hydroxylase deficiency causes vitamin $\mathrm{D}$ dependent rickets type 1B (VDDR1B). Vitamin D dependent rickets type 2A (VDDR2A), also referred to as vitamin $\mathrm{D}$ resistant rickets (VDDR), is due to a defect in the VDR. VDDR2B is a rare type of rickets owing to abnormal expression of a hormone response element-binding protein that disrupts the normal function of $\mathrm{VDR}^{13,14)}$.

The clinical and laboratory findings in patients with VDDR1A are similar to those seen in patients with nutritional rickets or hypophosphatemic rickets. However, VDDR1A can be discriminated from hypophosphatemic rickets by increased PTH and decreased 1,25(OH)2D concentrations and nutritional rickets by a normal $25 \mathrm{OHD}$ value. The hypophosphatemia in VDDR1A is an effect of high PTH level and renal excretion of phosphate. PTH promotes calcium reabsorption in the renal proximal tubules, and also promotes serum calcium through bone resorption ${ }^{15)}$. It also increases the alkaline phosphatase level ${ }^{15)}$. Most of the reported patients with VDDR1A showed low or undetectable 1,25(OH)2D levels. But there have been a few reported cases of patients with VDDR1A with normal $1,25(\mathrm{OH}) 2 \mathrm{D}$ levels ${ }^{6,16,17)}$. Nishikawa et al. ${ }^{18)}$ presented that liver mitochondrial CYP27A1 can catalyse 1a-hydroxylation of $25 \mathrm{OHD}$. A little bit increment of $1,25(\mathrm{OH}) 2 \mathrm{D}$ concentrations has been reported in CYP27B1 knockout mice after high vitamin $\mathrm{D}$ supplementation, suggesting the conversion from $25 \mathrm{OHD}$ to $1,25(\mathrm{OH}) 2 \mathrm{D}$ by a non-CYP27B1 enzyme ${ }^{14)}$. Wang et al. ${ }^{17)}$ reported two patients with VDDR1A who had normal 1,25(OH)2D values. Both exhibited a mild phenotype, and their mutations had partial enzyme function in vitro. So, VDDR1A should be suspected in cases with a mild or severe phenotype of rickets and normal or elevated values of $25 \mathrm{OHD}$ albeit $1,25(\mathrm{OH}) 2 \mathrm{D}$ concentrations are within the normal values.

The CYP27B1 gene is constituted of 9 exons spanning 5 $\mathrm{kb}^{19)}$. Until now, more than 70 mutations have been reported in the $C Y P 27 B 1$ gene in multiple ethnic groups ${ }^{10,14)}$. Several mutations in the $C Y P 27 B 1$ gene are more common in specific populations ${ }^{8,12)}$. Deletion of guanine 958 (958 delG) was reported on 20 French Canadian allele, and a microsatellite haplotype study revealed that these arose from a single ancestor ${ }^{12)}$. A seven nucleotide duplication in exon 8 (Phe443Profs ${ }^{\star} 24$ ) was reported in 14 affected alleles, and these arose from different populations with diverse microsatellite haplotypes ${ }^{12)}$.

To date, six Korean patients with VDDR1A have been investigated at a genetic study, and three different mutations have been reported ${ }^{8-10)}$. There are two frequent mutation points; c. $589+1 G>A$ in seven alleles and Phe443Profs ${ }^{\star} 24$ in four alleles. Our patient was also found to have two mutations common in the Korean population: c. $589+1 \mathrm{G}>\mathrm{A}$ and Phe443Profs ${ }^{\star} 24$. Thus, Korean patients with VDDR1A have been found to have only three different mutations in

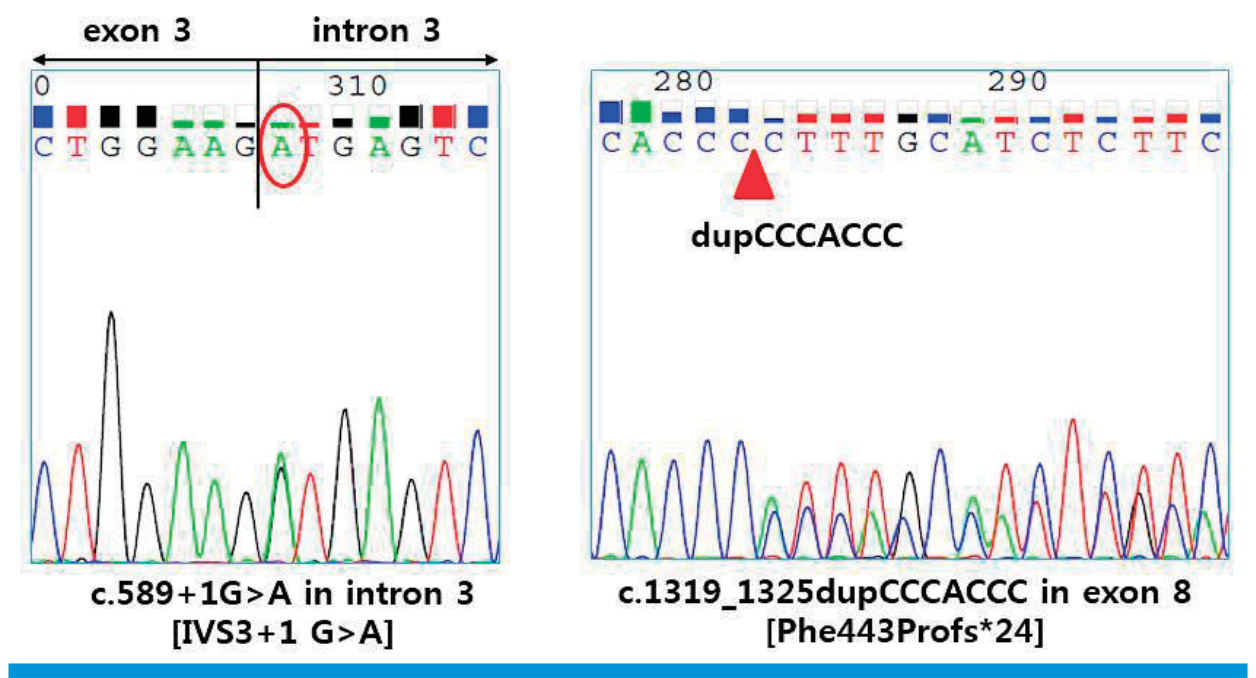

Fig. 2. Mutation analysis of the proband revealed a compound heterozygous mutation for c.589+1G>A and Phe443Profs*24 in the CYP27B1 gene. 
14 alleles.

Including our case, the clinical characteristics of seven patients with vitamin $\mathrm{D}$ dependent rickets type $1 \mathrm{~A}$ were summarized in Table 1. The most prevalent mutation is the $c .589+1 \mathrm{G}>\mathrm{A}$ splice donor site mutation, affecting 8 out of 14 alleles in Korean patients with VDDR1A. This mutation also have been reported in Japanese patients ${ }^{11}$. $G$ to $A$ change in the first nucleotide of an intron is a relatively frequent mutation and generally results in the skipping of the exon or initiation of potential splice sites ${ }^{17}$. The c.589+ $1 \mathrm{G}>\mathrm{A}$ mutation introduces a premature stop codon, and it causes disruption of 1a-hydroxylase activity.

The mutation of Phe443Profs ${ }^{\star} 24$ had been found in 5 of 14 alleles in Korean patients. This seven nucleotide duplication (CCCACCC) causes a premature TGA stop signal. It eliminates the heme-binding domain of 1a-hydroxylase and thus inactivate enzyme activity. Wang et al. ${ }^{12)}$ presented that six families of different ethnic groups had this mutation in association with four diverse microsatellite haplotypes. Kitanaka et al. ${ }^{11)}$ reported 10 different $C Y P 27 B 1$ gene mutations in 20 Japanese alleles, indicating that there was no single ancestor effect in Japanese population.

In conclusion, we present a case study of VDDR1A in which the patient was found to have a compound heterozygous mutation, Phe 443 Profs $^{\star} 24$ and c. $589+1 \mathrm{G}>\mathrm{A}$, in the CYP27B1 gene. Korean patients have been found to have only three different mutations in 14 alleles. This suggests that the mutation of the CYP27B1 gene is relatively homogeneous in the Korean population.

\section{Conflict of interest}

No potential conflict of interest relevant to this article was reported.

\section{Patient consent}

This study was approved by the institutional review board (IRB), and the consent was waived due to the nature of the retrospective study [IRB number CNUH-EXP2018-295].

\section{References}

1. Miller WL, Portale AA. Vitamin D 1a-hydroxylase. Trends Endocrinol Metab 2000;11:315-9.

2. Portale AA, Miller WL. Rickets due to hereditary abnormalities of vitamin D synthesis or action. In: Glorieux FH, Pettifor JM, Juppner H, eds. Pediatric bone. San Diego: Academic Press, 2003;58398.

3. Portale AA, Miller WL. Human 25-hydroxyvitamin D 1a-hydroxylase: cloning, mutations, and gene expression. Pediatr Nephrol 2000;14:620-5.

4. Breslau NA. Normal and abnormal regulation of $1,25(\mathrm{OH}) 2 \mathrm{D}$ synthesis. Am J Med Sci 1988;296:417-25.

5. Kumar R, Harnden D, DeLuca HF. Metabolism of 1,25-dihydroxy vitamin D3: evidence for side-chain oxidation. Biochemistry 1976;15:2420-3.

6. Demir K, Kattan WE, Zou M, Durmaz E, BinEssa H, Nalbantoğlu Ö, et al. Novel CYB27B1 gene mutations in patients with vitamin D-dependent rickets Type 1A. PLoS One 2015;10:e0131376.

Table 1. Clinical Characteristics of Seven Patients with Vitamin D Dependent Rickets Type 1A

\begin{tabular}{|c|c|c|c|c|c|c|c|c|c|}
\hline $\begin{array}{l}\text { Patient } \\
\text { no. }\end{array}$ & $\begin{array}{c}\text { Age at } \\
\text { diagnosis } \\
\text { (months) }\end{array}$ & Presentation & $\begin{array}{l}\text { Serum Ca } \\
(\mathrm{mg} / \mathrm{dL})\end{array}$ & $\begin{array}{l}\text { Serum P } \\
(\mathrm{mg} / \mathrm{dL})\end{array}$ & $\begin{array}{l}\text { Serum ALP } \\
(I \cup / L)\end{array}$ & $\begin{array}{c}\text { Serum PTH } \\
(\mathrm{pg} / \mathrm{mL})\end{array}$ & $\begin{array}{l}\text { Serum 25OHD } \\
(\mathrm{ng} / \mathrm{mL})\end{array}$ & $\begin{array}{l}\text { Serum 1,25- } \\
(\mathrm{OH}) 2 \mathrm{D}(\mathrm{pg} / \mathrm{mL})\end{array}$ & Mutation \\
\hline 1 & 5 & rachitic rosary & 6.4 & 4.0 & 2,043 & 1,320 & 27 & 9.2 & Phe443Profs*24/Phe443Profs*24 \\
\hline 2 & 5 & rachitic rosary & 5.9 & 3.6 & 1,326 & 750 & 77 & $<4$ & c. $589+1 \mathrm{G}>\mathrm{A} / 2561 \mathrm{G}>\mathrm{A}$ \\
\hline 3 & 7 & seizure & 5.2 & 6.2 & 665 & 750 & 38 & $<5$ & c.589+1G>A/Phe443Profs*24 \\
\hline 4 & 12 & bowed legs & 6.0 & 3.8 & 1,050 & 560 & N/A & $<7$ & $c .589+1 G>A / c .589+1 G>A$ \\
\hline 5 & 14 & femur fracture & 7.3 & 5.0 & 1,437 & N/A & 16 & $<5$ & c.589+1G>A/Phe443Profs*24 \\
\hline 6 & 13 & seizure & 4.8 & 4.3 & 1,665 & 178 & 75.1 & 5.3 & c.589+1G>A/c.589+1G>A \\
\hline 7 & 14 & seizure & 5.1 & 3.7 & 705 & 429 & 24.9 & 8.8 & c.589+1G>A/ Phe443Profs*24 \\
\hline
\end{tabular}

Abbreviations; ALP, Alkaline phosphatase; N/A, Not available. Data of Patients 1 to 5 are adopted from reference 9. Patient 6 is adopted from reference 10. Patient 7 is in this study.

${ }^{*}$ Nucleotide numbers refer to genomic DNA and are numbered from the transcription start site ${ }^{20}$. The reference sequence is available on the NCBI, Entrez, Nucleotide database: http://www.ncbi.n/m.nih.gov/Entrez; accession number AF 027152. 


\section{www.chikd.org}

7. Edouard T, Alos N, Chabot G, Roughley P, Glorieux FH, Rauch F. Short-and long-term outcome of patients with pseudo-vitamin D deficiency rickets treated with calcitriol. J Clin Endocrinol Metab 2011;96:82-9.

8. Kim CJ, Kaplan LE, Perwad F, Huang N, Sharma A, Choi Y, et al. Vitamin D 1alpha-hydroxylase gene mutations in patients with 1alpha-hydroxylase deficiency. J Clin Endocrinol Metab 2007;92: 3177-82.

9. Kim CJ. Vitamin D dependent rickets type I. Korean J Pediatr 2011;54:51-4.

10. Cho JH, Kang E, Kim GH, Lee BH, Choi JH, Yoo HW. Long-term clinical outcome and the identification of homozygous CYP27B1 gene mutations in a patient with vitamin D hydroxylation-deficient rickets type 1A. Ann Pediatr Endocrinol Metab 2016;21:16973.

11. Kitanaka S, Murayama A, Sakaki T, Inouye K, Seino Y, Fukumoto S, et al. No enzyme activity of 25-hydroxyvitamin D3 1a-hydroxylase gene product in pseudovitamin D deficiency rickets, including that with mild clinical manifestation. J Clin Endocrinol Metab 1999:84:4111-7.

12. Wang JT, Lin CJ, Burridge SM, Fu GK, Labuda M, Portale AA, et al. Genetics of vitamin D 1a-hydroxylase deficiency in 17 families. Am J Hum Genet 1998:63:1694-702.

13. Malloy PJ, Feldman D. Genetic disorders and defects in vitamin Daction. Rheum Dis Clin North Am 2012;38:93-106.
Bak NR, et al. • VDDR Type 1 Caused by CYP27B1 Mutation 115

14. Dursun F, Özgürhan G, Kırmızıbekmez H, Keskin E, Hacıhamdioğlu B. Genetic and clinical characteristics of the patients with vitamin D dependent rickets type 1A. J Clin Res Pediatr Endocrinol 2018 Oct 4doi: 10.4274/jcrpe.0121.

15. Akerstrom G, Hellman P, Hessman O, Segersten U, Westin G. Parathyroid glands in calcium regulation and human disease. Ann N Y Acad Sci 2005;1040:53-8.

16. Acar S, Demir K, Shi Y. Genetic causes of rickets. J Clin Res Pediatr Endocrinol 2017;9:88-105.

17. Wang X, Zhang MY, Miller WL, Portale AA. Novel gene mutations in patients with 1alpha-hydroxylase deficiency that confer partial enzyme activity in vitro. J Clin Endocrinol Metab 2002;87: 2424-30.

18. Nishikawa M, Yasuda K, Takamatsu M, Abe K, Nakagawa K, Tsugawa N, et al. Generation of 1,25-dihydroxyvitamin D3 in CYP27B1 knockout mice by treatment with 25-hydroxyvitamin D3 rescued their rachitic phenotypes. J Steroid Biochem Mol Biol 2019;185:71-9.

19. Fu GK, Lin D, Zhang MY, Bikle DD, Shackleton CH, Miller WL, et al. Cloning of human 25-hydroxyvitamin D 1 alpha-hydroxylase and mutations causing vitamin D-dependent rickets type I. Mol Endocrinol 1997;11:1961-70.

20. Fu GK, Portale AA, Miller WL. Complete structure of the human gene for the vitamin D 1a-hydroxylase, P450c1a. DNA Cell Biol 1997;16:1499-507. 